\title{
LAS ¿NUEVAS FORMAS? DE LOS ASENTAMIENTOS INFORMALES Formas y actores en la construcción de los barrios en el borde urbano del Área Metropolitana de Buenos Aires.
}

\author{
Autor: Dombroski, Lucas Jordán \\ Universidad: Instituto del Conurbano, UNGS - Becario doctoral CONICET \\ Directora de la tesis: Novick, Alicia \\ EMail: jordan.dombroski@gmail.com
}

\section{RESUMEN}

Los asentamientos, producto de tomas de tierra o loteos informales son un tema relevante en la bibliografía de América Latina, y han sido examinados en el Área Metropolitana de Buenos Aires desde sus orígenes en la década de 1980. Diversos estudios han tratado sobre el proceso de construcción de éstos en su preocupación por guardar cierta regularidad para asemejarse a los barrios "formales" y diferenciarse de las estigmatizadas villas. Si bien su descripción en términos de regulares constituye una idealización, en los últimos años se evidencia nuevos entramados de actores con particulares relaciones, que construyen el hábitat de forma diferente. Con el objeto de dar cuenta de las distintas formas con que los barrios se construyen, se propone examinarlos desde la ocupación inicial y a lo largo del proceso de construcción, entendiendo que su conocimiento resulta en una contribución importante para reflexionar sobre el diseño e implementación de políticas públicas.

Palabras clave: asentamientos informales, formas, actores, borde urbano.

\begin{abstract}
Settlements, the result of land seizures or informal subdivisions, are a relevant topic in the bibliography of Latin American, and have been examined in Metropolitan Area of Buenos Aires since its origins in the 1980s. Several studies have dealt with the construction process of these in their concern to keep a certain regularity to resemble the "formal" neighborhoods and differentiate themselves from the stigmatized villas. Although its description in terms of regular constitutes an idealization, in recent years there is evidence of new networks of actors with particular relationships, who build the habitat in a different way. In order to account for the different ways in which neighborhoods are built, it is proposed to examine them from the initial occupation and throughout the construction process, understanding that their knowledge results in an important contribution to reflect on the design and implementation of policies public.
\end{abstract}

Key words: informal settlements, forms, network of actors, urban edge. 


\section{ASENTAMIENTOS INFORMALES COMO TRANSFORMACIONES TERRITORIALES RECIENTES EN EL BORDE URBANO DEL AMBA}

Los asentamientos, producto de tomas de tierra o loteos informales son un tema relevante en la bibliografía de América Latina (Hardoy, Satterthwaite, 1987; Clichevsky, 2003), y han sido examinados en el Área Metropolitana de Buenos Aires (AMBA) desde sus orígenes en la década de 1980 (Izaguirre, Aristizabal, 1988; Merklen, 1997). Diversos estudios han tratado sobre el proceso de construcción de éstos en su preocupación por guardar cierta regularidad en la definición de la cuadrícula, los lotes y la reserva de espacios comunes, para asemejarse a los barrios "formales" y diferenciarse de las estigmatizadas villas (Cravino, 2009). Si bien la descripción del asentamiento en estos términos constituye una idealización, en los últimos años se evidencia una multiplicidad de actores que con distintas estrategias y recursos, tanto desde la ocupación inicial como a lo largo del proceso, construyen el hábitat de forma diferente, sobre todo por las particulares vinculaciones que se establecen entre los sectores populares, organizaciones intermedias, autoridades públicas y el crimen organizado.

La población de villas y asentamientos informales ha ido en crecimiento en las últimas décadas en el AMBA, llegando a principios del nuevo siglo a más de un millón viviendo en alrededor de mil barrios (Cravino, 2009). Este aumento se debió, según diversos estudios, a las dificultades cada vez mayores de acceso al mercado inmobiliario formal (Del Río, 2008; Ciccolella, Baer, 2008). Mientras que las villas se encuentran sobre todo en la Ciudad de Buenos Aires y en los municipios limítrofes a ésta (primera corona del AMBA), los asentamientos se han ido configurando en el borde urbano, en municipios de la segunda corona desde los años '80, sobre grandes polígonos de suelo vacante o rural. Las primeras, poseen una morfología intrincada con pasillos que conectan edificios con pocos espacios libres. Los segundos, se caracterizan por estructurarse a partir de trazados más regulares y abiertos con parcelas donde generalmente habitan una o dos familias en viviendas individuales. Si bien, villas y asentamientos suelen asociarse por la informalidad que les caracteriza, se trata de dos fenómenos muy diferentes, sobre todo desde el punto de vista morfológico. Punto de vista que ha sido poco explorado en estos territorios, sobre todo para el caso de los asentamientos.

La reactivación posterior a la crisis económico-política de fines de 2001, generó condiciones que cambiaron substancialmente las formas de crecimiento. La expansión del mercado de trabajo, con la demanda de mano de obra para la construcción, y las corrientes migratorias internas y de otros países sudamericanos, transformaron las áreas de borde, de suelo degradado y con escasa accesibilidad, con la construcción de vivienda social y asentamientos informales. Estos nuevos barrios, tanto producto de la autogestión de los sectores populares como producto directo de intervenciones estatales, se explican fundamentalmente por políticas públicas focalizadas y sectoriales (Catenazzi, 2011) que fueron impulsadas en estos años de crecimiento económico. En donde desde las administraciones locales además, se definieron políticas muy diversas, muchas veces en competencia con las administraciones vecinas, que buscaban inversiones privadas o del Estado nacional o provincial sin mensurar el costo o impacto en las tierras disponibles a transformar.

En los territorios de borde, donde se entiende que el Estado ha perdido su centralidad -o monopolio relativo- en la acción sobre el proceso de urbanización, por la marcada extensión de la informalidad que se evidencia, la ciudad se va construyendo con los recursos y estrategias que los distintos actores ponen en juego, y con las formas urbanas que dan respuesta a los intereses específicos de éstos. En relación a lo anterior, se postula que existen momentos coyunturales de entramados de actores a partir de los cuales se inauguran formas diferentes de ocupación y construcción del hábitat en los asentamientos. En ese sentido, el análisis de estas formas urbanas es capaz de iluminar las modalidades de operar de estos actores sobre el territorio, pero además constituye un elemento central a la hora de reflexionar sobre la formulación de instrumentos y políticas de ordenamiento eficaces, capaces de favorecer el desarrollo de políticas de inclusión.

Para comprender estas transformaciones del borde desde las especificidades del territorio, es preciso desarmar la idea de Estado que se asume como monolítico en una dirección de intervenciones y políticas (Lascoumes, Le Galés, 1984); y considerar más bien, la interacción de los actores en términos de autoridades públicas y actores sociales. Esta postura respecto de los actores en el análisis, permite visualizar con mayor precisión el accionar de las autoridades de la administración, y considerar de manera diferente a los actores sociales en su capacidad de incidencia sobre las transformaciones. 
Tal como señala Solá Morales (1997), el análisis se plantea en las relaciones entre las diferentes formas de crecimiento (morfología) y las fuerzas sociales que constituyen su motor y su contenido. En este contexto, con el objeto de dar cuenta de las formas con que se construyen los asentamientos, es propicio examinarlos desde la ocupación inicial y a lo largo del proceso de construcción del hábitat, considerando la diversidad de modos de operar de múltiples actores. Desde ese planteo, resulta particularmente interesante el proceso de construcción de una serie de barrios que constituyen dos asentamientos, en una zona de borde entre el límite de los municipios de Moreno y José C. Paz, desde el inicio de estos en 2006 hasta el 2016.

\section{LOS ASENTAMIENTOS EN LA FRONTERA ENTRE MUNICIPIOS}

Los dos asentamientos se han configurado en un mismo territorio de borde, entre los ejes radiales de extensión Oeste (FC Sarmiento) y Noroeste (FC San Martín) que se desarrollaron como "tentáculos" a partir de las vías de ferrocarril y en torno a sus estaciones (Chiozza, 1983), con una base aérea militar mediante, en la frontera entre los municipios de Moreno y José C. Paz. Dicha frontera, como un límite jurisdiccional imaginario, no cambia la complejidad de un territorio producto de las dinámicas de urbanización metropolitana, pero si oficia de límite en relación a las políticas que una u otra administración aplica sobre él, por lo que resulta importante entender a ambas desde esta perspectiva.

Los dos municipios desarrollaron, durante los últimos 15 años políticas públicas en el territorio de borde y en relación al hábitat popular marcadamente distintas. El municipio de Moreno, como una administración más antigua -fundada en 1864, incluyendo parte de Gral. Sarmiento hasta 1889 cuando se rectificaron los límites-, posee mayores recursos económicos, administrativos y humanos y ha logrado imponer políticas locales con fuerte incidencia en las transformaciones recientes, sobre todo a través de un Instituto Autárquico creado durante la crisis. Estas políticas buscaron favorecer la producción del hábitat desde el acompañamiento a los pobladores en la "autoproducción" con una fuerte presencia y gestión territorial, captando así financiamiento con programas dirigidos a la mejora del hábitat. El municipio de José C. Paz, por su parte, se desprendió del primero luego de dicha rectificación de límites, y con la disolución de Gral. Sarmiento en 1994, cuando pasó a conformar los partidos de José C. Paz, Malvinas Argentinas y San Miguel. Como un municipio de reciente conformación, ha sido más dependiente de las políticas centrales del gobierno nacional buscando inversión en la producción de viviendas con planes federales y otras obras públicas de gran envergadura.

Como característica propia de los municipios de segunda corona, ambos poseen una cobertura de servicios básicos de agua potable y desagües cloacales que se encuentra por debajo de la mitad de la población servida, y un crecimiento que responde a una dinámica metropolitana muy significativa, de tipo extensivo sobre suelo antes rural, incorporando $16,2 \%$ y $13,5 \%$ de población, llegando respectivamente, a 452.505 para Moreno y 265.981 para José C. Paz, (en el último período intercensal 2001-2010). Este crecimiento se dio en un contexto nacional de fuerte inversión pública en materia de soluciones habitacionales, tanto de mejora del hábitat como en construcción de viviendas nuevas; pero que, sin políticas de suelo activas, habiéndose agotado en los '90 el stock de lotes económicos ${ }^{1}$ aprobados antes del decreto-ley de Usos del Suelo y Ordenamiento Territorial $N^{\circ} 8912 / 77$, simultáneamente, se dio una expansión de la ciudad informal producto de las mismas mejoras en las expectativas económicas y las consecuentes migraciones. En este contexto, en 2012 se sanciona la Ley provincial $N^{\circ} 14.449$ de Acceso Justo al Hábitat que rectifica y ratifica algunos aspectos de la ley antes mencionada, he implica profundos cambios en relación a las políticas públicas que se pueden llevar adelante, habilitando a los municipios a darle marco de legalidad a los procesos y prácticas populares de autoconstrucción y autoproducción en el camino hacia una regularización formal del hábitat.

En la metrópoli, la extensión de la mancha urbana, desde los centros tradicionales -generalmente entorno a estaciones de los trenes- se ha ido dando encontrando algunos límites "duros" y otros más "blandos o permeables". En la zona de estudio, la ciudad se extendió hasta la década del '70 por el eje noroeste, sorteando la base de la VII Brigada aérea, dejando un polígono de propiedad privada vacante atravesado por un arroyo, y por el norte junto a la Ruta Provincial n 24 (RP24) encontró otro límite en el predio de una gran industria de cerámicas, que se había instalado en la década del '50 y que influyó fuertemente en el desarrollo de la ruta provincial. Desde entonces, el área entre la base y el arroyo Las Catonas permaneció con características rurales de producción extensiva e intensiva, pero en el sector donde se conformaron los barrios se desarrolló la explotación del suelo arcilloso. (Grafico 1)

\footnotetext{
${ }^{1}$ Estos loteos populares fueron un fenómeno alternativo a las anteriores formas de hábitat popular, como las de los inquilinatos en conventillos o la ocupación en villas en las áreas centrales de la ciudad. Estos tienen un auge en las décadas de 1940,1950 y 1960 durante las migraciones internas, producto del sistema de sustitución de importaciones. (Torres, 1993)
} 


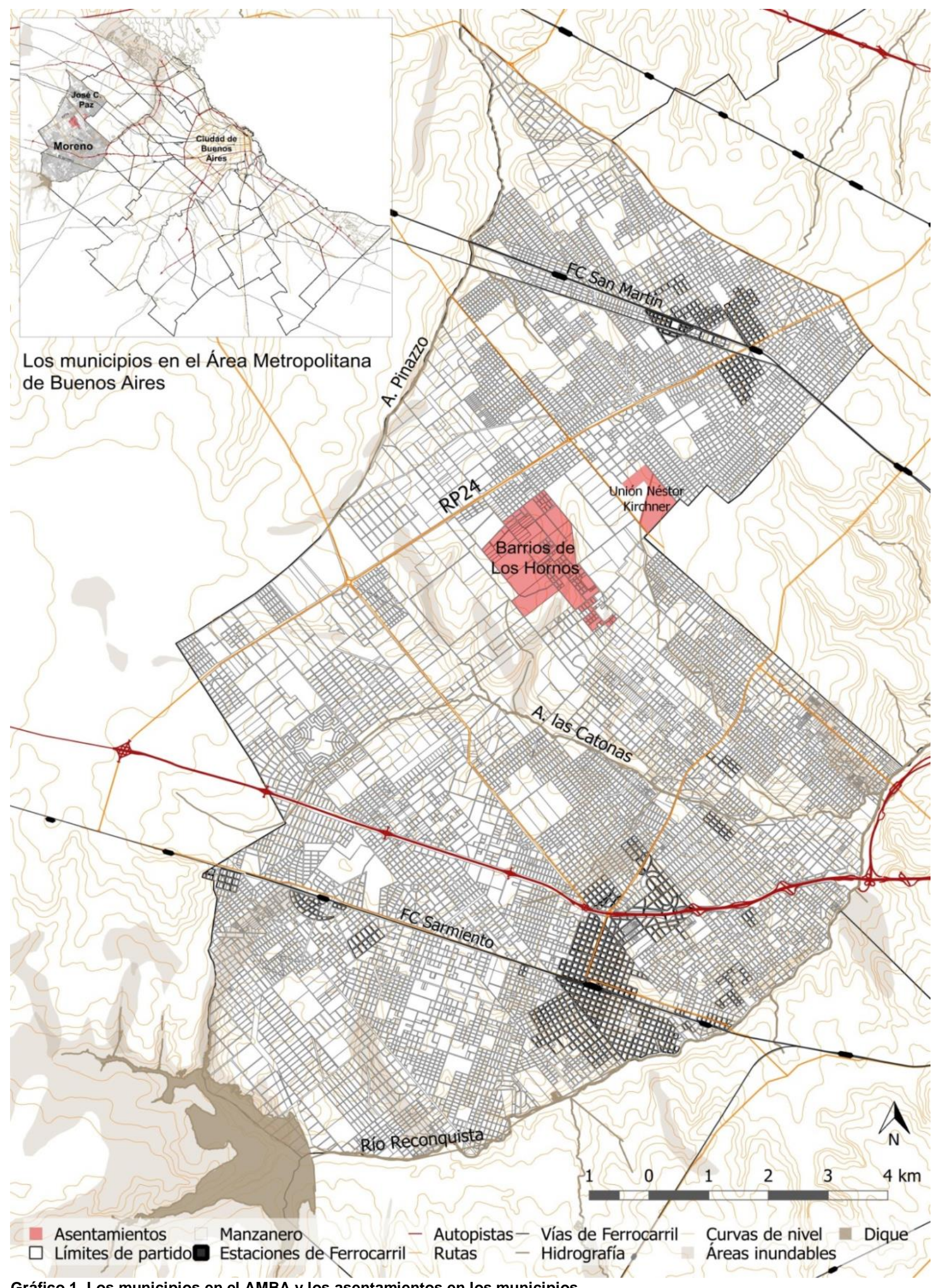

Gráfico 1. Los municipios en el AMBA y los asentamientos en los municipios

Elaboración propia, a partir de cartografía base desarrollada en proyecto PIO-CONICET-UNGS dirigido por Novick y Catenazzi, ICO, UNGS. 
Desde el 2006 en adelante se empezaron a dar las primeras ocupaciones de tierra a continuación del tejido que databa de los años '70, perforando los bordes "blandos" que delimitaban las cavas explotadas por familias y viveros de quintas en la zona de Moreno. Luego entre el 2009 y el 2011 se dan dos importantes transformaciones a cada lado de la frontera, un proyecto de viviendas con servicios en Moreno, y una obra de canalización de un arroyo en José C. Paz, -en ambos casos, con otros proyectos latentes- que promueven de diferentes maneras otras ocupaciones, con una serie masiva de tomas de tierra durante los dos próximos años, para luego entrar en un proceso de densificación y completamiento con el protagonismo creciente de un mercado inmobiliario informal de venta de suelo y viviendas. Desde ese proceso, los barrios de Los Hornos (norte de Moreno) y Unión Néstor Kirchner (sur de José C. Paz), como asentamientos de reciente extensión, se han ido configurando, sobre tierras decapitadas por cavas junto a afluentes del arroyo Las Catonas y otros intersticios de suelo poco aptos para ser habitados. Son resultado de un proceso de extensión de una década, abarcando un total de 600 hectáreas de suelo y albergando aproximadamente 50.000 habitantes. (Grafico 2)

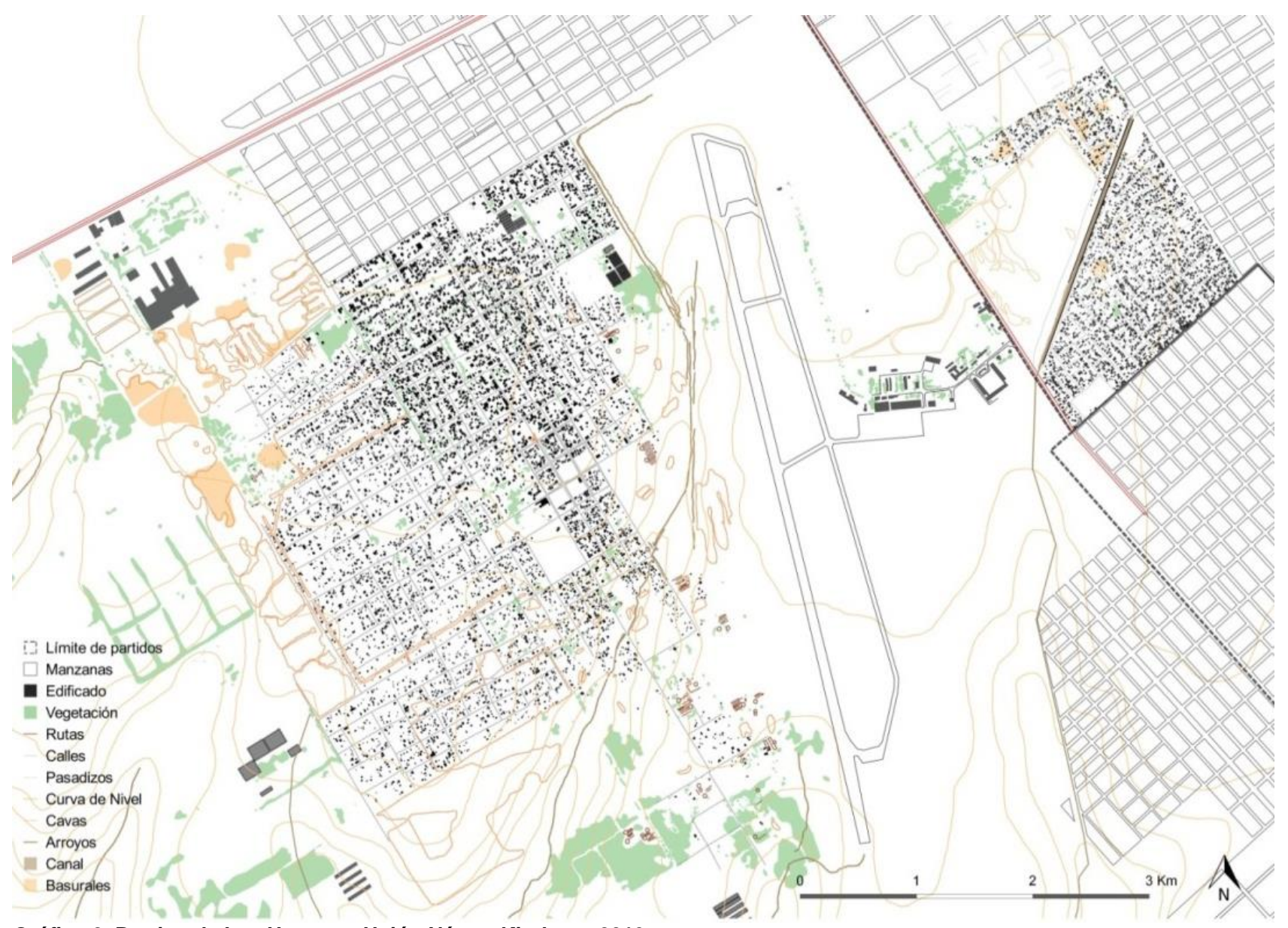

Gráfico 2. Barrios de Los Hornos y Unión Néstor Kirchner. 2016

Elaboración propia con Q-gis a partir de imágenes de Google Earth

\section{CONSTRUCCIÓN DE LOS BARRIOS, MOMENTOS Y ENTRAMADOS DE ACTORES}

En la construcción de los barrios se identificaron momentos coyunturales de entramados de actores a partir de los cuales se entiende que se inauguran formas diferentes de ocupación y construcción del hábitat, constituyendo así áreas diferenciadas. Estos entramados se leen en torno a la aplicación de una política urbana, intervención o transformación específica.

\subsection{El caso de los barrios de Los Hornos. Moreno}

Se identificaron tres momentos distintos en la conformación de los barrios que inauguraron a su vez formas diferentes de ocupación y de construcción del hábitat. Estas formas diferentes coexisten en el tiempo en la construcción de los barrios, pero morfológicamente se diferencian tanto en la ocupación inicial como a lo largo del proceso de urbanización. Primero, desde el 2006 en adelante se dio un inicio y expansión gradual 
del asentamiento a partir de una serie de tomas llevadas adelante por familias, mayormente organizadas, con un municipio que tenía como política por entonces no acompañar los pedidos de desalojo. Segundo, desde fines del 2009 e inicio de 2010 se desarrolló un proyecto habitacional y de generación de redes de servicios, entre un instituto autárquico municipal, una asociación civil y pobladores a reubicar, que más adelante activó actuaciones puntuales de algunos de los actores en la extensión de la urbanización informal. Tercero, desde fines de 2012 se desató una extensión del asentamiento de ocupación veloz y de muy baja densidad a partir de nuevos actores que intervinieron desde un mercado inmobiliario informal de compra y venta de suelo y vivienda.

\subsubsection{Familias organizadas en la ocupación de tierras y construcción de barrio}

Desde el 2006 se da el inicio y expansión gradual del asentamiento a partir de una serie de tomas llevadas adelante por familias mayormente organizadas, y con un gobierno local que tenía como política en esos años no acompañar los pedidos de desalojo, dando lugar así al barrio 18 de Julio. El proceso que se inició implicó, en primera instancia, una serie de tomas de suelo privado en predios lindantes al tejido urbano preexistente y zonas de loteos en quinta que databan de los años '70, en una segunda instancia, la extensión sobre polígonos rurales desplazando a algunas familias que explotaban el suelo arcilloso en la fabricación de ladrillos. Para fines de 2009 se había llegado a un total de suelo ocupado de aproximadamente 50 hectáreas entre los caminos rurales existentes (Ricchieri y Portugal), que eran por entonces los únicos ejes que atravesaban la zona. (Grafico 3)

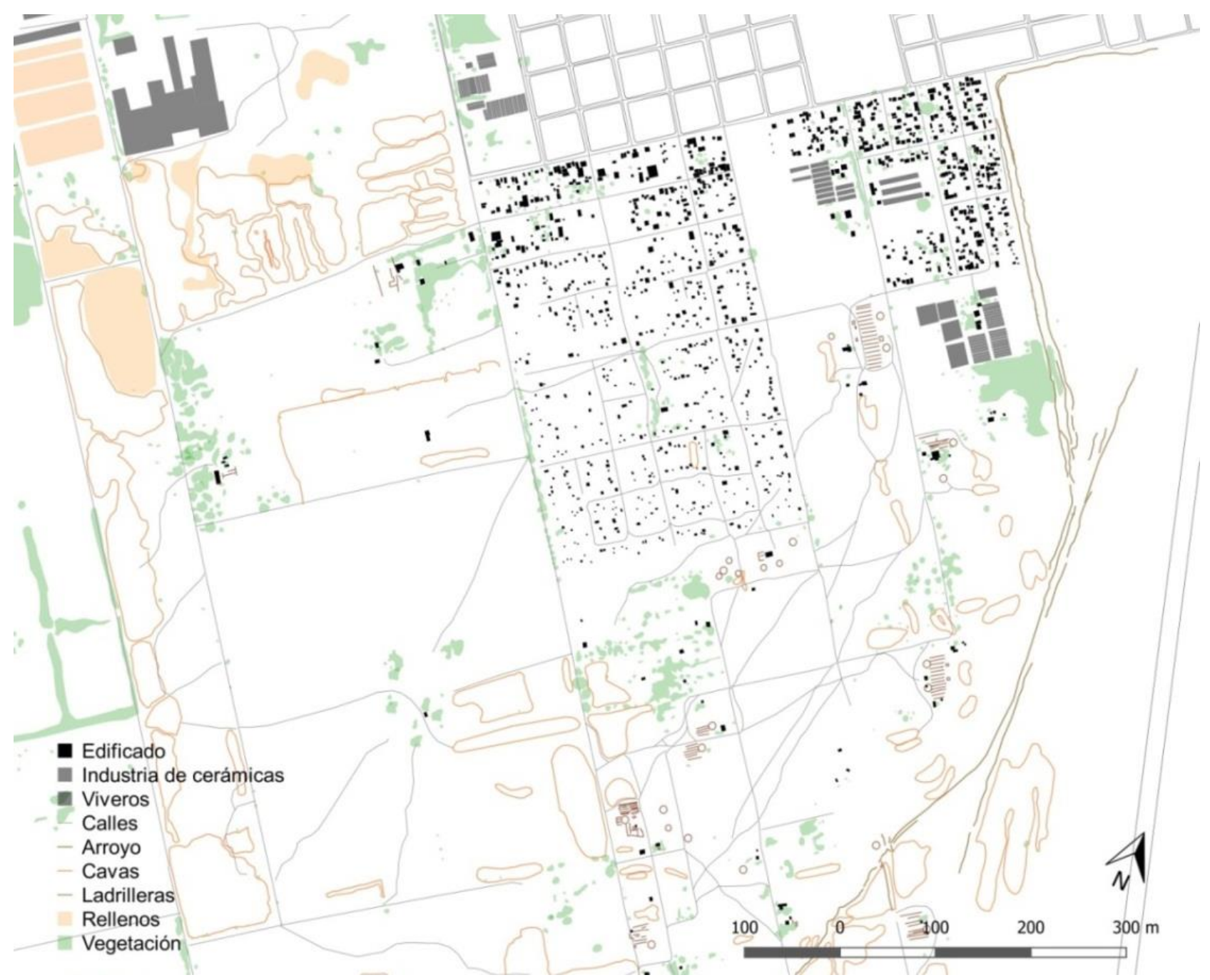

Grafico 3. Las primeras tomas. Barrio 18 de Julio. 2008

Elaboración propia con Q-gis a partir de imágenes de Google Earth

Estas primeras ocupaciones que se dan en Los Hornos guardan cierta relación con las de principios de la década del '80, pues tanto los actores que están por detrás en las transformaciones, como las estrategias que estos llevan adelante y las formas urbanas resultantes son semejantes. Esas primeras tomas de tierra y 
loteos informales, se caracterizaban por su respeto a las reglamentaciones vigentes en cuanto al tamaño mínimo de los lotes y el trazado de las calles, para favorecer su ulterior regularización (Di Virgilio, et al. 2012), y tenían como protagonistas a grupos de familias que eran acompañadas por alguna organización política o eclesiástica que los asistía en el difícil camino que va desde la ocupación inicial, la resistencia a los posibles desalojos y la posterior autoconstrucción de las viviendas y autoproducción del hábitat. Los mismos habitantes realizaban los trazados de las calles, dejaban zonas libres para los futuros equipamientos, construían y acondicionaban los espacios públicos y desarrollaban o demandaban la provisión de servicios, colectivamente (Grafico 4). En estos loteos, la manzana regular es el elemento que se repite y ordena el territorio, pero la dinámica de permanente transformación en la autoconstrucción progresiva del hábitat y la vivienda realizada por cada familia o en forma colectiva con la colaboración de los vecinos, implica modificaciones de las edificaciones y también redefiniciones de límites medianeros y avances de lo edificado sobre el espacio público.
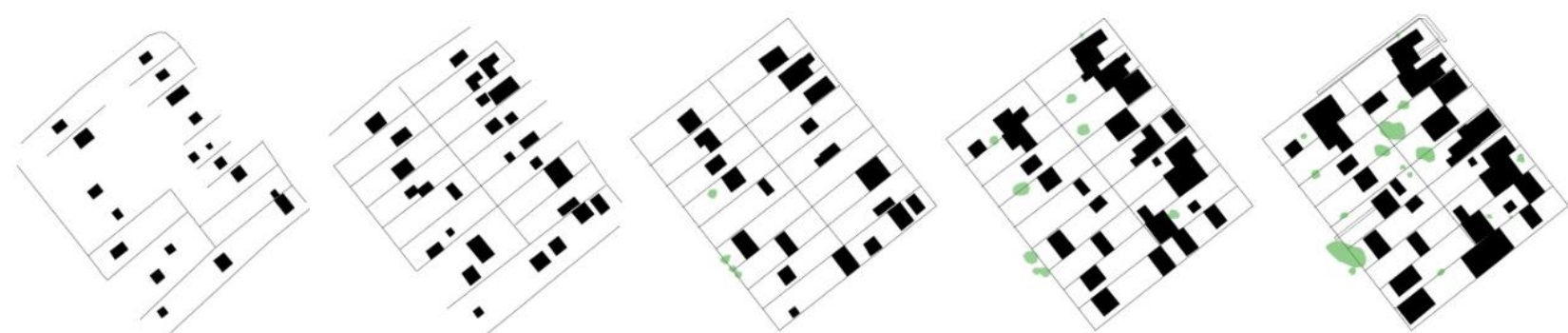

Grafico 4. Los cambios en una manzana del Barrio 18 de Julio. (2008-2017)

Elaboración propia con Q-gis a partir de imágenes de Google Earth

Coincidente con estas ocupaciones en la zona, se confecciona un nuevo Código de Zonificación del Municipio que termina sancionándose en 2008, y que implica una extensión de la zonificación del área complementaria. La zona, que hasta entonces era mayormente rural, se ve especialmente afectada a este cambio, y el sector de Los Hornos pasa a tener un área zonificada con uso residencial y de producción agraria intensiva, entre el sector rural extensivo al oeste y la VII Brigada Aérea como uso específico al este. Este cambio en la zonificación le permite al municipio intervenir en el sector en la extensión de la urbanización.

\subsubsection{Funcionarios públicos, organizaciones intermedias y pobladores en la construcción de los Hornos.}

Desde fines del 2009 e inicio de 2010 se desarrolla una articulación entre múltiples actores en función de un proyecto habitacional y de generación de redes de servicios que dan lugar al Barrio de Los Hornos ${ }^{2}$. El proyecto se llevó a cabo sobre 9 hectáreas de suelo fiscal del banco de tierras municipal obtenido por prescripción adquisitiva administrativa (según ley $n^{\circ}$ 24.320/94), y con la extensión de los servicios y la mejora de la calle Portugal, más adelante se activan actuaciones puntuales de algunos de los actores en la extensión de la urbanización informal sobre suelo privado y fiscal. (Grafico 5)

\footnotetext{
${ }^{2}$ El barrio que se inicia en 2009 es nombrado "Los Hornos" y es a partir de aquí que lo demás barrios del asentamiento adoptan esta denominación al ser englobados. Al mencionar "los barrios de Los Hornos" se hace referencia a todo el asentamiento.
} 


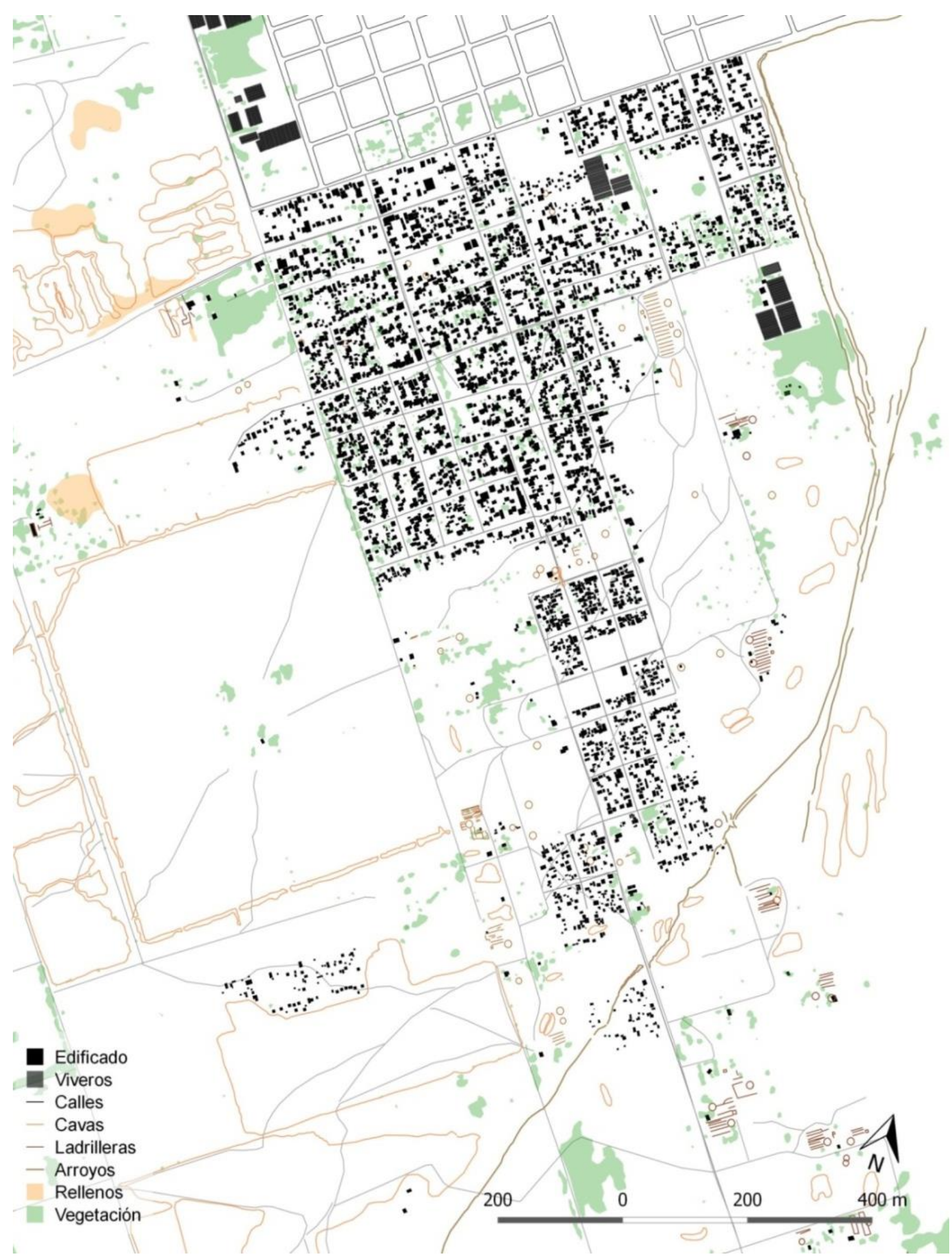

Grafico 5. Los Hornos I y II y otras ocupaciones. 2011

Elaboración propia con Q-gis a partir de imágenes de Google Earth

A los fines de reubicar población que se había instalado en torno a un barrio planificado de otra localidad del municipio, el Instituto de Desarrollo Urbano, Ambiental y Regional (en adelante IDUAR) inició un proceso de negociación convocando a la asociación civil Madre Tierra (en delante MT) como mediadora entre los 
intereses del instituto autárquico municipal y el de los pobladores. El resultado de las negociaciones desembocó en la generación mancomunada del barrio de Los Hornos en sus etapas I (2009) y II (2010) en donde se evidencia un proceso abierto a una multiplicidad de actores intervinientes que tuvieron protagonismo en la construcción de ciudad.

El área sobre el que se desarrolló el barrio de Los Hornos era suelo que ingresó al erario municipal ya parcelado, como parte del viejo remanente de lotes económicos anteriores al Decreto Ley 8912/77, que aún subsistían vacantes por la lejanía que tenían con respecto al tejido urbano. El IDUAR se encargó de proveer estos lotes con financiamiento para el desarrollo de los servicios, mientras que MT acompañó a los vecinos en el proceso de traslado, ocupación y construcción de la vivienda y el hábitat. Los Hornos se conformó rápidamente a partir de la concreción de las primeras calles de tierra abiertas por las máquinas del municipio y el relleno de las cavas. Entre los servicios que se proveyó se encuentra el tendido de electricidad y el saneamiento (red de desagües pluviales conectados a los arroyos, pozos y tanques de agua colectivos conectados a las viviendas a través de una red, y pozos negros individuales).

Luego de la generación del barrio de Los Hornos y de la apertura y mejorado de la calle Portugal desde el IDUAR y con aprobación del Juzgado de Paz se decidió relocalizar población proveniente de desalojos de otra zonas del municipio en las tierras fiscales en torno a Los Hornos ${ }^{3}$. Estas relocalizaciones, y otras tomas de predios privados cercanos, se dieron con distintas modalidades de una forma muy conflictiva, despertando contradicciones en la gestión y en relación al accionar de los privados tenedores del suelo y las fuerzas de seguridad. Las relocalizaciones combinadas con algunas tomas organizadas dan lugar a los barrios Seis Manzanas y La Unión, que se ubican cerca del arroyo Cuartel V. Además, se dieron ocupaciones sobre un predio fiscal que se reserva para la construcción a futuro de un polideportivo, así como otras sobre el margen del arroyo, que fueron desalojadas en múltiples ocasiones durante el 2011 y el 2012. Muchos de estos desalojos se dan sin una respuesta de relocalización de la población, a pesar de que en diciembre de 2010 el Consejo Deliberante había declarado la Emergencia Habitacional en el territorio municipal.

En Los Hornos I, las casillas se instalaron en los fondos de los lotes en un principio, para después en el tiempo, cuando llegaran los servicios les resultara más barato a las familias la extensión de la red dentro de la parcela hasta la nueva vivienda que hicieran con materiales más sólidos al frente del lote. Esto implicó además, que no hubiera invasión de las construcciones sobre la línea municipal (Grafico 6). Gracias al acompañamiento de MT con la asistencia técnica en la autoconstrucción y la obtención de financiamiento externo para la mejora del espacio público o de las viviendas, se ha logrado guardar la regularidad del barrio de Los Hornos, a partir de lo cual resulta factible la intervención del Estado con la implantación de equipamientos comunitarios y provisión de servicios urbanos en general.
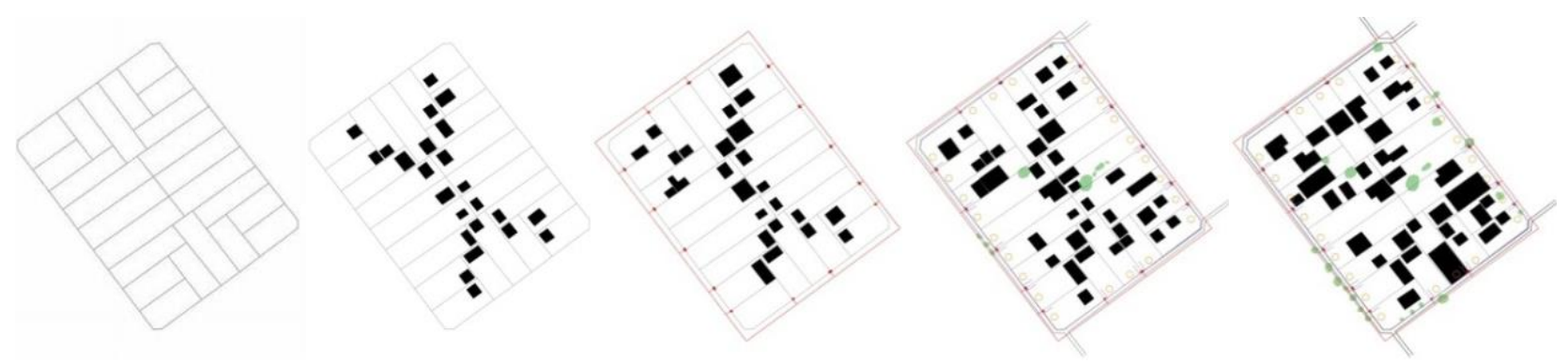

Grafico 6. Los cambios en una manzana del barrio Los Hornos I. (2009-2017)

Elaboración propia con Q-gis a partir de imágenes de Google Earth

Como ya se mencionó, las ocupaciones se venían dando sobre predios ubicados entre las dos calles rurales preexistentes, con excepción de algunas áreas que el municipio y los habitantes lograron reservar en función de proyectos comunitarios; en 2012 esto cambia y se da una primera ocupación sobre las tierras de la industria de cerámicas, por parte de unas 50 familias mayormente provenientes del barrio 18 de Julio, en una zona alta entre grandes cavas, así como una extensión del asentamiento en la zona norte. ${ }^{4}$

\footnotetext{
${ }^{3}$ Esto, así como otros procesos de tomas de decisiones y articulaciones entre los actores, se determinó a partir del relevamiento de medios locales y de entrevistas semiestructuradas a funcionarios municipales y referentes barriales.

4 "Nos organizamos en este predio porque hace dos años que el municipio nos prometió entregarnos tierra en Los Hornos y jamás cumplió. Venimos del barrio 18 de Julio a tomar la tierra" dice un protagonista de la toma a un medio local (http://desalambrar.com.ar)
} 


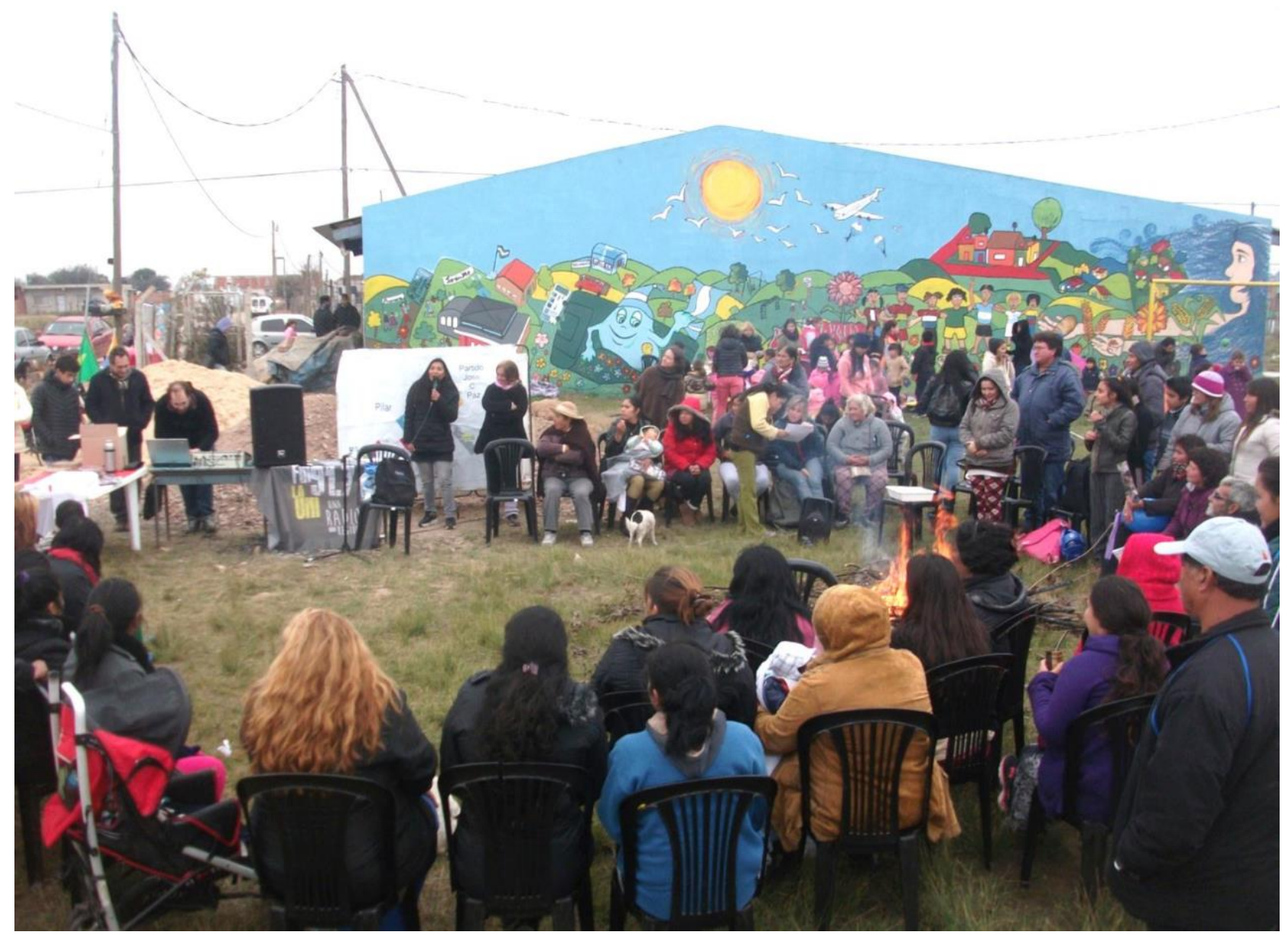

Grafico 7. Familias convocadas, funcionarios públicos y otros actores en Los Hornos. 2016

Toma propia (2016)

\subsubsection{Loteadores piratas y crimen organizado en la ocupación de tierras y venta de lotes y viviendas.}

Hasta fines de 2012 la extensión del asentamiento se venía dando en forma progresiva, con actuaciones puntuales del municipio en los últimos años que implicaron varios desalojos, hasta la llegada de nuevos actores con más recursos, tanto económicos como políticos, que se lograron imponer, apropiándose en sólo dos meses de una porción de suelo semejante a la que se había ocupado en los anteriores cinco años y que movilizaron un mercado inmobiliario informal disponiendo de lotes y viviendas construidas específicamente con el objeto de venderlas, dando lugar así a los barrios 8 de Diciembre, 23 de Diciembre y 8 de Enero. (Grafico 8)

A diferencia de las primeras tomas, en los últimos años los asentamientos estuvieron marcados por una fuerte impronta del mercado inmobiliario informal, tal como señala Cravino (2009) que entiende que con la extensión del espacio construido desde este mercado se alteran las condiciones de factibilidad de los programas de regularización. Si bien la autora se refiere sobre todo a la extensión de lo construido en función del mercado de alquileres para las villas, aquí puede verse una producción de suelo y viviendas con los fines específicos de venta tanto de suelo como de vivienda, que extienden el asentamiento en baja densidad sobre grandes superficies sin una estructura inicial de espacios públicos o de circulación.

La ocupación de suelo en la conformación de los tres barrios mencionados se da en baja densidad sobre 250 hectáreas. A partir de esta ocupación extensiva sobre el suelo, donde se delimitan lotes que no se ocupan inicialmente, se abren espacios en donde los loteadores informales ponen en venta el suelo y producen viviendas para vender. A partir de estas ocupaciones el municipio interviene activamente y gestiona la compra de 70 hectáreas de suelo a la industria de cerámicas, lo que le permitió actuar rápidamente en la generación de algunas calles. 


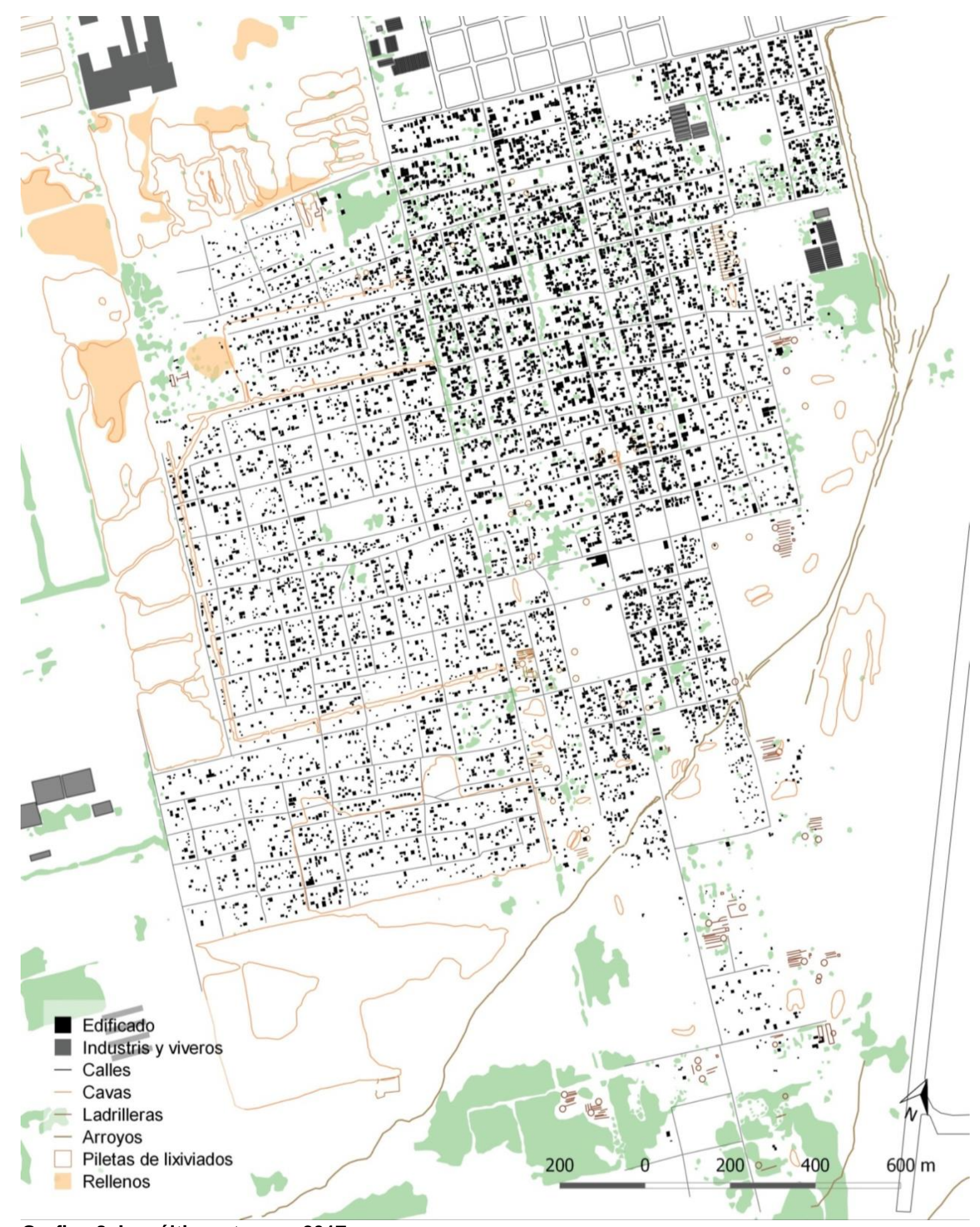

Grafico 8. Las últimas tomas. 2017

Elaboración propia con Q-gis a partir de imágenes de Google Earth

A pesar de la velocidad con que se ocupan las tierras en este momento, las tomas están lejos de ser un fenómeno espontáneo, pues luego de la mencionada extensión del barrio 18 de Julio sobre suelo de la industria de cerámicas, y de la ocupación de las 50 familias en una zona alta entre cavas, se produce un 
loteo pirata ${ }^{5}$ sobre 35 has. antes de las ocupaciones más extensivas. Paradójicamente, el detonante de la construcción más irregular del asentamiento, fue en gran medida, un loteo informal muy regular que como proyecto antes había sido presentado ante el municipio y no resultó aprobado. Este loteador pirata que decide lotear informalmente, luego de la negativa por parte del gobierno local, se diferencia fundamentalmente de otros actores del proceso porque es poseedor de este suelo.

El loteo pirata constó del armado de 35 manzanas bien delimitadas y regulares con 24 lotes cada una, de una superficie que varía entre 200 y $400 \mathrm{~m} 2$. La evolución de la manzana en el tiempo permite visualizar la delimitación inicial bien definida de los lotes y la línea municipal (división entre espacio público y privado). Luego se registra una ocupación rápida de algunos de los lotes con viviendas precarias, que se pueden definir como provisorias antes de la instalación de viviendas más sólidas. Un fenómeno particular, y diferente a lo que se venía dando en el asentamiento es que en este proceso algunos lotes permanecen vacíos y otros son unificados -duplicando superficie- a lo largo de los años. (Grafico 9)

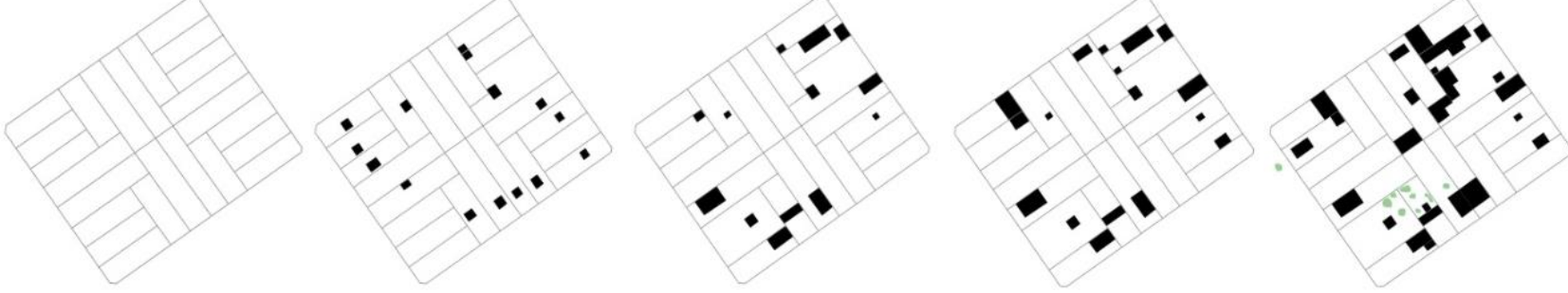

Grafico 9. Los cambios en una manzana del loteo pirata. (2012-2017)

Elaboración propia con Q-gis a partir de imágenes de Google Earth

Las otras ocupaciones posteriores al 2013, vinculadas sobre todo al crimen organizado, (asociado sobre todo, a la venta de droga, armas y la trata de personas) constaron inicialmente de un parcelamiento sobre los grandes macizos de suelo, pero sin una estructura de manzanas con calles que la definan. Estos elementos se van definiendo a partir de las primeras ocupaciones o ventas de suelo y/o vivienda en donde cada loteador informal va poniendo en juego su capacidad de apropiación del territorio. En este proceso, el hábitat se va conformando con algunas parcelas que subsisten, se consolidan y agrupan definiendo así, a lo largo del proceso de materialización, manzanas irregulares. Mientras, otras parcelas desaparecen y dan paso a las calles de acceso. Las familias que compraron lotes o viviendas en estos nuevos barrios provienen mayormente, como desplazados de la Ciudad de Buenos Aires por los aumentos en los alquileres formales e informales, que se suman a los que ya residían en la zona y que por densificación de los primeros barrios o por el crecimiento propio de las familias terminan mudándose.

Los lotes se fueron definiendo en relación a algunos ejes sobre los cuales dan frente. Estos ejes son los perpendiculares a la calle Ricchieri, que hace de nexo hacia el exterior, y, paralelo a esta última se conformaron otros secundarios que son conectores entre los principales y se definen como senderos 0 calles que se entrecortan. Entonces, la particularidad de estos procesos es que se parte de la definición del lote, se definen los ejes conectores de las parcelas y, entonces, se configuran las manzanas. En este sentido, a diferencia de las primeras ocupaciones el elemento ordenador aquí es el lote y no la manzana. (Grafico 10)

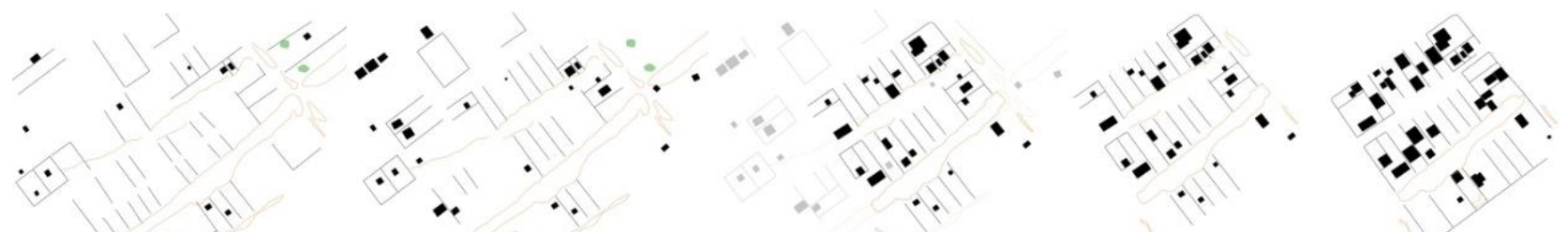

Grafico 10. Los cambios en lotes y edificaciones en las ocupaciones vinculadas al crimen organizado. (2012-2017)

Elaboración propia con Q-gis a partir de imágenes de Google Earth

${ }^{5}$ Clichevsky (2003) plantea que en estos loteos piratas se realiza una convocatoria por parte de un urbanizador a los futuros ocupantes
del terreno o vivienda, con una negociación mediante que incluye "la promesa de compraventa" y de un futuro legalizado, además del
"apoyo" de políticos locales, que comprometidos con la urbanización intermedian frente a las autoridades para evitar cualquier desalojo. 


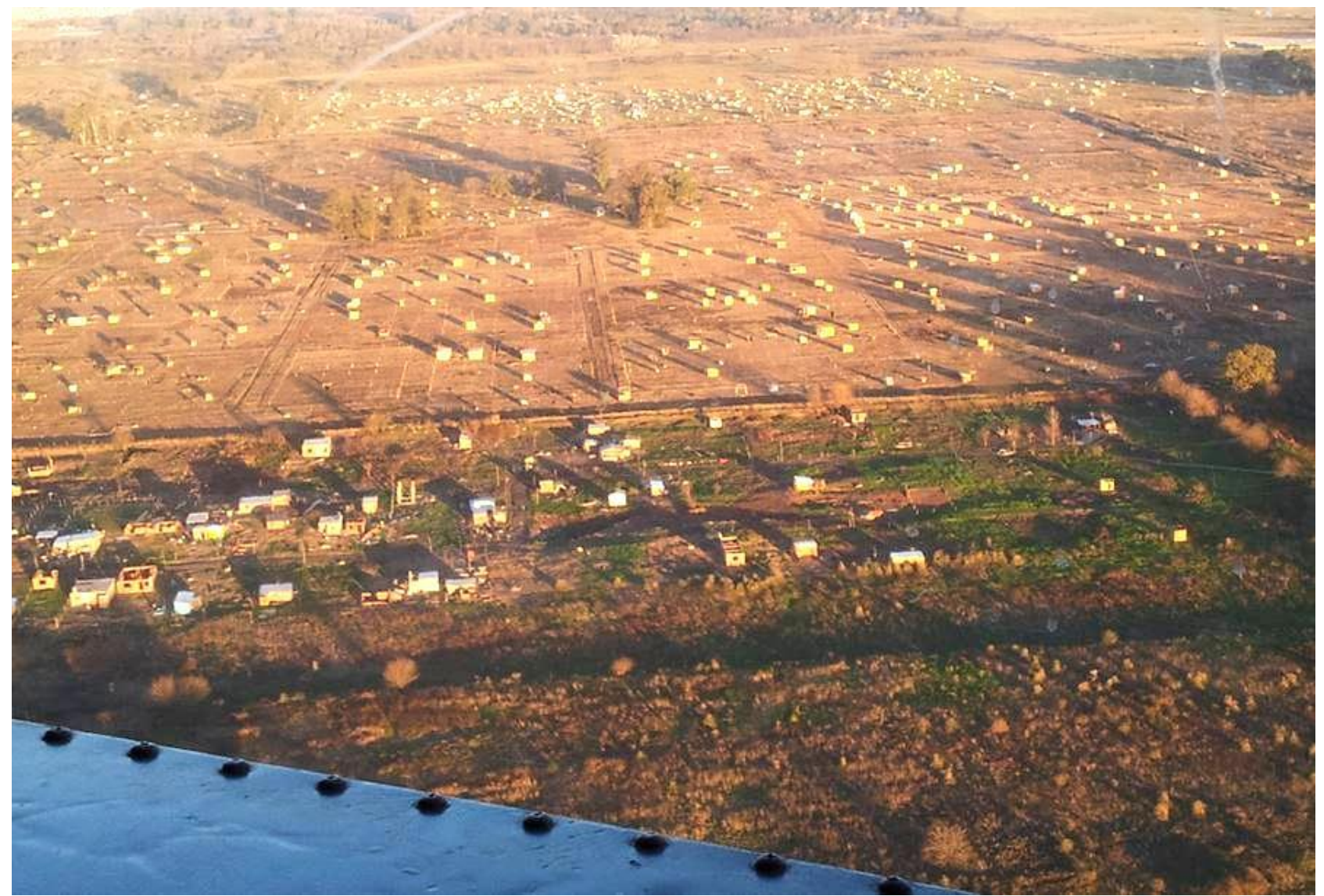

Grafico 11. El loteo pirata y las otras tomas más irregulares. (2012)

Fuente: IDUAR

Con estas últimas ocupaciones no se reservaron áreas de uso común para la generación futura de espacios verdes o equipamientos, y con la venta informal de lotes entre áreas ocupadas y consolidadas se introdujeron usos distintos al puramente residencial como pequeñas industrias y comercios sobre parcelas más grandes. En relación a esto, a través de la Ordenanza Municipal № 5.686 en 2016 el municipio crea un paquete de instrumentos en función de la Ley provincial 14449 que se aplica inicialmente sobre el territorio de los barrios de Los Hornos a los fines de resolver estos problemas vinculados la extensión del asentamiento. Se crea el Consejo Local de Vivienda, Hábitat y Derecho a la Ciudad, el Registro de Cartografía Social y Participativa y el Fondo de Contribución Desarrollo Integral. También mediante la misma, se designa al IDUAR como autoridad de aplicación de la ley provincial.

\subsection{EL caso del Unión Néstor Kirchner. José C. Paz}

Existen dos momentos distinguibles en la ocupación y construcción del barrio en José C. Paz. Uno que se inicia desde 2011 con varias tomas y desalojos con la participación de grupos de familias, punteros y funcionarios políticos, donde se ocupa gran parte del área. Un segundo momento, que se inicia en 2013 y consiste en el loteo pirata de un sector del barrio que se había mantenido sin ocupar hasta que se resolvió una causa judicial vinculada a la ocupación del resto del predio.

\subsubsection{La toma organizada del predio}

En un contexto donde el gobierno local pone su atención sobre los predios vacantes de su territorio -tanto privados como fiscales-, a los fines de localizar planes de vivienda o realizar otro tipo de obras, se logra la obtención de financiamiento para la canalización de un afluente del arroyo Catonas. Con dicha obra en ejecución desde el 2011, sobre un predio privado, el municipio propone a los dueños la realización de un parque industrial sobre el polígono de 110 has.

Sin lograr acuerdo sobre el proyecto inicialmente, a mediados de ese año se da una primera toma de tierra, sobre el predio, que fue rápidamente reprimida y desalojada. Luego a principios de 2012 se da una segunda, sobre alrededor de 80 has., que avanzó y se consolidó rápidamente, registrándose ya para marzo 
de 2012 alrededor de 1000 personas en unas 500 carpas y construcciones precarias a lo largo del predio ${ }^{6}$ con algunos loteos informales de terrenos de $200 \mathrm{~m} 2$ aproximadamente ${ }^{7}$ (Grafico 12). Esta toma organizada de tierra, con punteros políticos vinculados a la administración como participes, cambia la relación de fuerzas del municipio con los propietarios y se logra un acuerdo marco de desarrollo del parque industrial con una porción del predio destinado a vivienda social para los ocupantes, así como también, en paralelo se inicia una causa por parte de los dueños denunciando la participación del municipio en la toma.

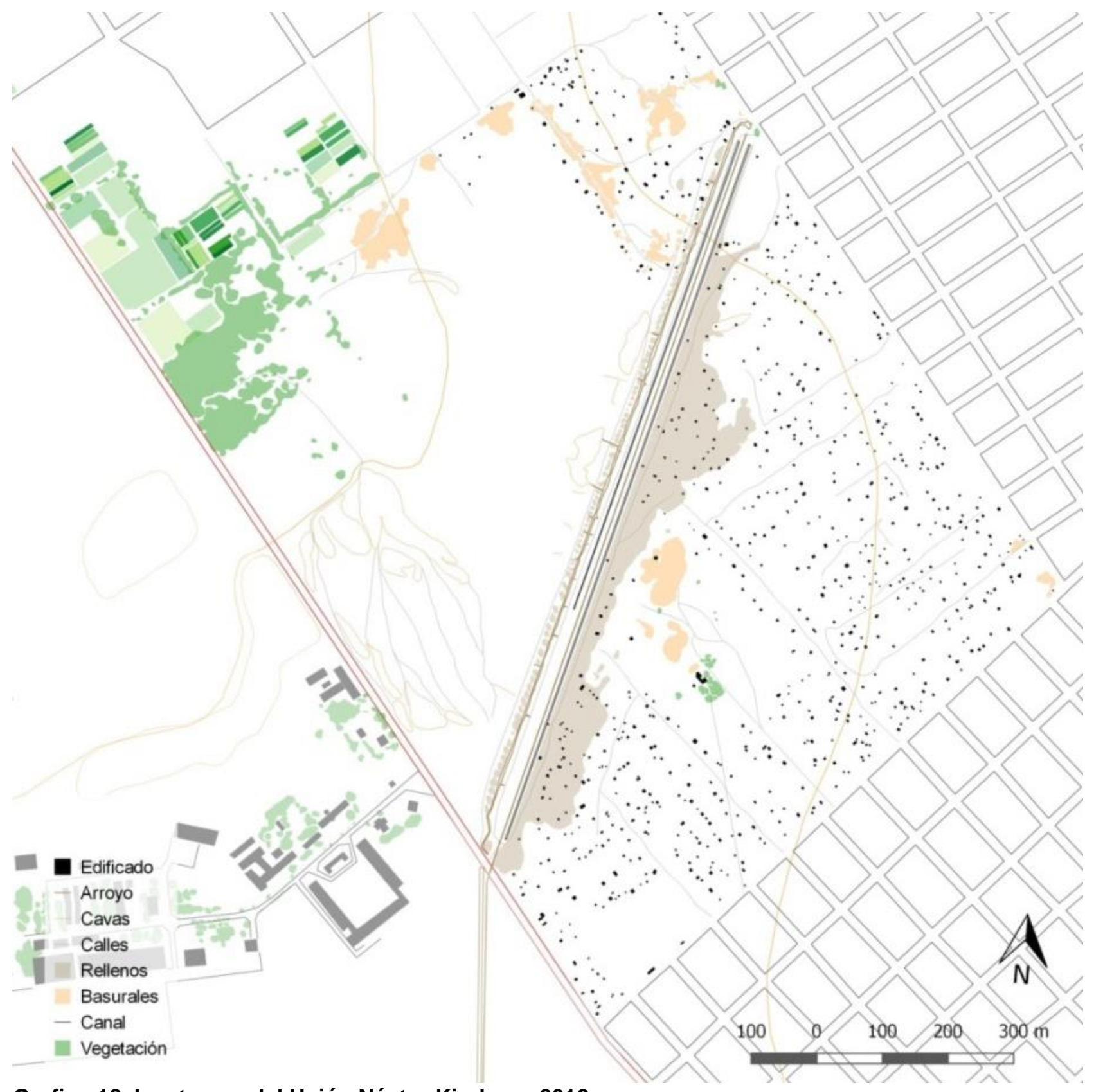

Grafico 12. Las tomas del Unión Néstor Kirchner. 2012

Elaboración propia con Q-gis a partir de imágenes de Google Earth

A pesar del acuerdo con los propietarios del predio para la realización del parque industrial, desde la administración no se logra desalojar a los habitantes que contaron más adelante con la intervención de un diputado nacional y el impulso con sanción para la expropiación del predio desde esta cámara legislativa, así como, en paralelo, el desarrollo de un proyecto de urbanización del barrio por parte de la Comisión Nacional de Tierras para el Hábitat Social que fue presentado ante el juez que llevaba la causa, con

\footnotetext{
${ }^{6}$ Según denuncia de la comodataria de un club barrial y vecinos de San Miguel y José C Paz.

7 Denuncia de la propietaria del predio. Donde consta carta documento del empleado de empresa dueña y cuidador del predio que intima al gobierno municipal a retirar camiones y maquinaria municipal.
} 
fundamentos muy claros sobre la política nacional respecto a no reprimir a las familias que participan en las tomas.

Si bien hubo algunos loteos informales luego de la toma, ésta se da con ocupación efectiva de toda la superficie y una división aproximada de los lotes en alrededor de unos 200 a 300m2. También, se delimitaron algunos trazados que permitieron el ingreso de algunos camiones y máquinas durante el traslado de algunas familias. Consolidándose así rápidamente algunas manzanas y lotes algo irregulares. (Grafico 13)
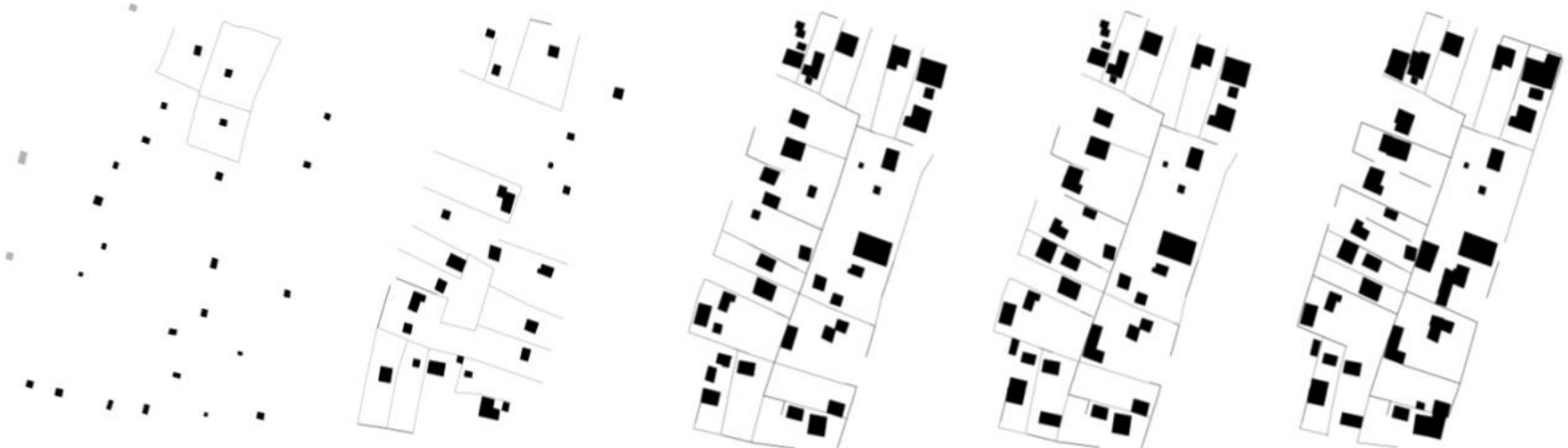

Grafico 13. La evolución de una manzana del Unión Néstor Kirchner. (2012-2017)

Elaboración propia con Q-gis a partir de imágenes de Google Earth

La participación en la construcción del barrio, por parte de las familias y algunas organizaciones políticas como el Movimiento Evita, en este proceso supuso además el armado de un grupo con designación de delegados por manzanas que tenían por objetivo asegurarse que no se instale alguna organización criminal, así como controlar algunos otros aspectos de orden urbano según los problemas que se advertían en distintas etapas.

Este primer momento, que se inicia por las acciones directas del municipio sobre el predio así como por otras de articulación con punteros y los propietarios, y del desarrollo de un proyecto luego frustrado, que además es atravesado por un proceso de judicialización, tiene idas y vueltas de unos y otros actores. Sin embargo, en la ocupación el municipio tiene una acción directa a través de punteros políticos y por las acciones que desarrolló previamente en el predio abriendo caminos por donde las familias ingresaron. Las familias organizadas junto a organizaciones políticas por su parte fueron los protagonistas principales en la construcción del barrio.

\subsubsection{El loteo pirata en el corazón del barrio}

La resolución de la causa judicial, hasta entonces caratulada como "usurpación" se resuelve considerando que no existió delito -porque no hubo ejercicio de violencia- debido a que los ocupantes atravesaron el cerco perimetral por las áreas que el municipio había abierto durante la realización de la obra de canalización. Este fallo colocó en una posición diferente al cuidador que había logrado mantener la custodia sobre 6 has. de suelo en el área central del predio, y que dadas las circunstancias decidió comenzar a lotearlas desde el 2013. (Grafico 14)

El proceso de loteo resultó muy particular por la manera de ocupación desde los bordes de la anterior toma hacia la vivienda del cuidador que se mantuvo en el centro, en un momento en el que el asentamiento ya se estaba consolidando. En la venta de estos lotes se resignó espacios de circulación a costa de áreas edificables. Esto se debió fundamentalmente a dos razones, la primera, vinculada al proceso mismo, donde se inicia el loteo cunado el resto del barrio ya tenía definido algunos ejes y lotes con viviendas que daban el fondo con este espacio, con lo cual las vías de acceso se vieron reducidas; la segunda, está vinculada a un mayor aprovechamiento del suelo por parte del loteador pirata. 


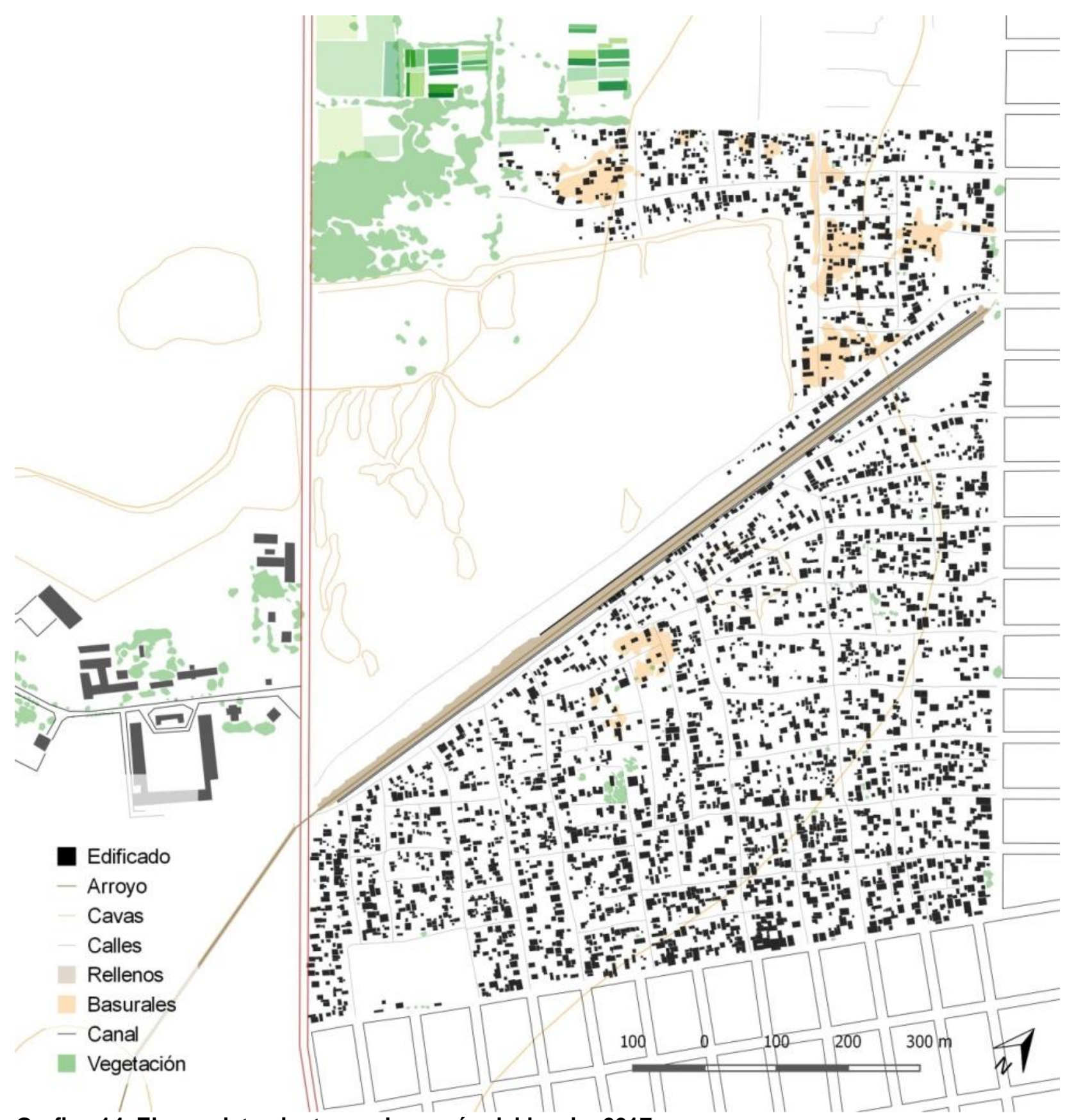

Grafico 14. El completamiento en el corazón del barrio. 2017

Elaboración propia con Q-gis a partir de imágenes de Google Earth

La forma de lo que se podría entender como un completamiento del tejido dentro del asentamiento se encuentra estructurada por la vivienda del ex cuidador del predio en el centro, y el eje que conecta esta con el exterior del barrio, que a su vez estructura a partir de otras vías secundarias en formas de pasillos los accesos a las demás viviendas. Encontrándose las edificaciones del borde en las áreas inicialmente loteadas y las del centro como más recientes, puede evidenciarse en los lotes del borde un proceso de densificación, con edificios de hasta cuatro pisos de altura con departamentos mínimos en alquiler. Por otra parte, la configuración propia de ésta área ha sido un elemento importante que permitió la instalación de una organización mafiosa vinculada a la venta de droga en la zona. (Grafico 15) 

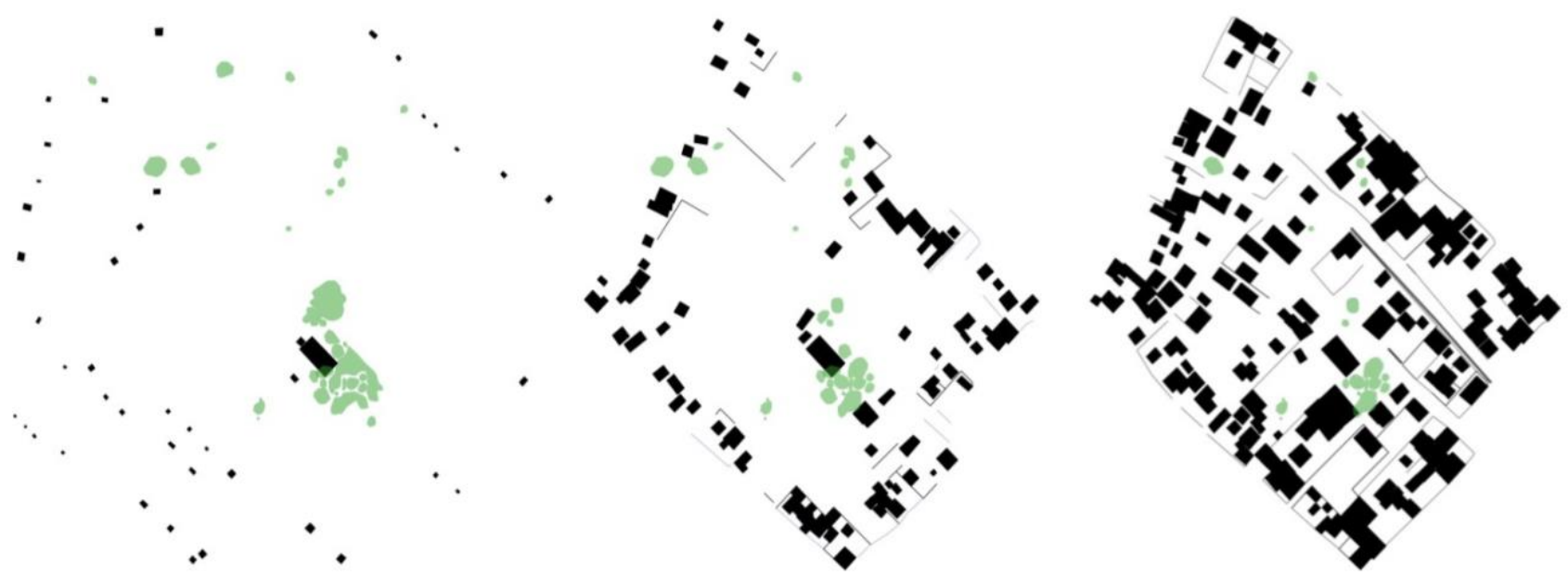

Grafico 15. El loteo pirata al interior del barrio. (2013-2017)

Elaboración propia con Q-gis a partir de imágenes de Google Earth

\section{REFLEXIONES SOBRE FORMAS Y ACTORES EN LA CONSTRUCCIÓN DE LOS ASENTAMIENTOS}

El análisis de los asentamientos, como un fenómeno con sus especificidades para el caso de la ciudad metropolitana estudiada, fue enfocado desde la relación entre los entramados de actores y las formas con que estos construyen. En los términos planteados, ha quedado demostrado que la construcción de estos barrios está lejos de ser un proceso lineal en donde las autoridades públicas definen políticas concretas e intervenciones, y actúan en consecuencia, mientras, las clases populares son grupos de familias que se instalan de manera espontánea u organizada en las áreas vacantes. El análisis exige considerar las vinculaciones complejas entre múltiples actores que actúan a diferentes escalas y en dinámicas territoriales con lógicas propias, que obligan a redefinir constantemente, en el proceso, sus estrategias y posiciones.

La escalada del conflicto vinculado al acceso a suelo, vivienda, y en última instancia hábitat, en la sucesión de eventos descripta, que procura constantes respuestas y la generación de nuevas demandas y necesidades a satisfacer, da cuenta de las dificultades de las administraciones locales para resolver la problemática de acceso al hábitat de manera integral. Suponiendo que la resolución de dicho problema forma parte de la agenda de la administración. Lo anterior responde a una lógica sectorial y segmentada respecto de la aplicación de las políticas urbanas, definición de proyectos e intervenciones, como respuesta a lo que se entiende como una problemática de déficit de vivienda muy puntual. En este sentido, se puede advertir la dificultad por parte de los intérpretes encargados de la implementación para comprender los problemas que traerían aparejadas las intervenciones en un territorio con las complejidades ya descriptas.

En las primeras ocupaciones que se dieron en los dos asentamientos, donde participaron grupos de familias y organizaciones políticas se evidencia una preocupación por la construcción de barrios, en el difícil camino que va desde la ocupación inicial, la resistencia a los posibles desalojos y la posterior autoconstrucción de las viviendas y autoproducción del hábitat. En estos casos los gobiernos locales tienen incidencia en el proceso de diferentes maneras, tanto siendo permisivos o directamente motivando la ocupación por medio de distintas estrategias.

Una articulación multiactoral que es preciso considerar en estos procesos, desde sus formas de ocupar y construir el hábitat, es la de funcionarios públicos, organizaciones intermedias y pobladores, en su conformación como entramado, que ha demostrado ser exitosa en términos de resolver la problemática para algunas familias específicas en el caso de Los Hornos, pero que, sobre todo por su localización, desencadeno un proceso de tomas de tierra acelerado sobre otras áreas. A pesar de estas ocupaciones que se desataron, los predios que el municipio decidió reservar para la instalación de algunos equipamientos comunitarios permanecieron sin ser tomados, incluso con el paso de los años. Esto último, habla de las capacidades de los gobiernos locales para direccionar y controlar algunos procesos en la medida que actúen o proyecten actuar en función de las necesidades de la comunidad con consenso y cohesión social. La ocupación de vacíos en los asentamientos con proyectos comunitarios a futuro es un tema no menor en relación a las posibilidades de desarrollar políticas urbanas o intervenciones específicas que puedan acompañar estos procesos, guardando cierta regularidad para una posterior regularización y (re)urbanización. Como contraparte, el caso del proyecto de desarrollo de un parque industrial con vivienda social en las áreas tomadas de José C. Paz resultó infructuoso a pesar de la insistencia del gobierno local. 
Claramente, la resolución de "los problemas urbanos requiere de la definición de recursos e instrumentos de gestión que permitan pasar a un urbanismo centrado en la cohesión social y fuertemente operativo" (Reese; Catenazzi, 2010:112), y en ese sentido el papel de las organizaciones intermedias como MT resulta esencial a los fines de llevar adelante políticas urbanas integrales y en una interacción de tipo más horizontal entre los actores, o aún más, en relación a la conformación de un entramado de actores en pos de una intervención especifica.

Por las características que ha adoptado el fenómeno en los últimos años, se puede poner en cuestión la idea de la construcción de los barrios de manera "regular", como estrategia, para diferenciarse de las estigmatizadas villas, ya que, así como algunos actores se preocupan por esta cuestión, otros tienen intereses diferentes y logran imponer sus lógicas. La emergencia de un mercado inmobiliario informal que dispone de nuevos recursos vinculados a la promoción de sus productos ${ }^{8}$, así como el crimen organizado que se desplaza desde diferentes áreas, hacia donde las fuerzas de seguridad ven limitado su accionar, han puesto en evidencia sus formas de apropiarse de tierras y ejercer control territorial.

En una relación de complicidad y conflicto con los funcionarios públicos; los loteadores piratas, y el crimen organizado que se comporta como desarrollador inmobiliario informal, poseen formas de ocupación y construcción marcadamente diferentes en los barrios estudiados. En relación a los primeros, en una estrategia por maximizar las ganancias, adoptan formas que van desde muy regulares en la división de la propiedad y el espacio público a formas con densidad edilicia y trazados más intrincados como los de las villas. En cuanto a los segundos, se puede observar una preocupación que va más allá de la producción de ganancias con las ventas de los lotes y las viviendas que producen, que supone un ejercicio de control, sobre extensas áreas, en disputa con las fuerzas de seguridad e intervenciones de otras autoridades.

Las distintas estrategias y recursos de los actores en entramados específicos, se traducen en formas muy diversas de los asentamientos, no solo en la instancia de la ocupación, sino que también a lo largo del proceso de construcción de estos. La diversidad señalada, en relación a los diferentes trazados que se configuran, las manzanas, los lotes y las edificaciones, así como también los elementos topográficos y las redes de servicios, hablan de procesos complejos que deben ser comprendidos tanto desde las formas, como desde los modos de operar de los entramados de actores que protagonizan estas transformaciones.

La comprensión de este fenómeno exige indagar más profundamente sobre la historia morfológica y de los actores desde los años ' 80 a la actualidad, y un estudio muy detallado del papel que juegan nuevos actores, como el crimen organizado como promotor inmobiliario informal. Esto obliga a incorporar más casos de estudio en la indagación respecto de patrones morfológicos definidos, que desde este planteo será un elemento central para reflexionar sobre la formulación de instrumentos y políticas de ordenamiento y regularización eficaces, capaces de favorecer el desarrollo de políticas de inclusión.

\section{BIBLIOGRAFÍA}

CATENAZZI, A. (2011). "El territorio como entrada a los proyectos integrales". En Gestión municipal y proyectos integrales. Entre lo estratégico y lo cotidiano. Programa de Mejora de la Gestión Municipal. Ministerio del Interior - BID. Buenos Aires, pp. 99 - 114.

CHIOZZA, E. (1983). "La integración del Gran Buenos Aires", en Buenos Aires, historia de cuatro siglos, tomo II, dirigida por José Luis y Luis Alberto Romero, Editorial Abril, Buenos Aires.

CICCOLELLA, P. Y BAER, L. (2008). Buenos Aires tras la crisis: ¿Hacia una metrópolis más integradora o más excluyente? En Ciudad y Territorio, Estudios Territoriales, Vol. XL, № 157. Madrid.

CLICHEVSKY, N. (2003). Pobreza y acceso al suelo urbano. Algunos interrogantes sobre las políticas de regularización en América Latina. Serie Medio Ambiente y Desarrollo. CEPAL, Naciones Unidas (75).

CRAVINO, M. (org). (2009). Los mil barrios (in)formales. Buenos Aires: Universidad Nacional de General Sarmiento.

\footnotetext{
${ }^{8}$ Internet a través de web's y redes sociales, así como cadenas de mensajes telefónicos han pasado a tener un papel muy relevante en relación a la promoción de estos productos inmobiliarios.
} 
CRAVINO, M. (2009). La metamorfosis de la ciudad informal en el Área Metropolitana de Buenos Aires. Revista Lider, 15(11), 31-55.

DI VIRGILIO, M., ARQUEROS MEJICA, M. Y GUEVARA, T. (2012). Estrategias de acceso al suelo ya la vivienda en barrios populares del Área Metropolitana de Buenos Aires. Revista Brasileira de Estudos Urbanos e Regionais.

DEL RíO, J. (2012). El lugar de la vivienda social en la ciudad: Un análisis de la política habitacional desde el mercado de localizaciones intra-urbanas y las trayectorias residenciales de los habitantes. Tesis de Doctorado. Universidad Nacional de La Plata. Facultad de Humanidades y Ciencias de la Educación.

DEL RíO, J. (2008). El acceso al suelo en la política habitacional en el área metropolitana de Buenos Aires. Notas metodológicas sobre un objeto problemático. En $X$ Jornadas de investigación del Centro de Investigaciones geográficas y del Departamento de Geografía, Facultad de Humanidades y Ciencias de la Educación, Universidad Nacional de La Plata, ISSN 1850-0862.

Gobierno de la Provincia de Buenos Aires (2012).Ley provincial № 14.449 de Acceso Justo al Hábitat.

Gobierno de la Provincia de Buenos Aires (1994). Ley provincial N² 24.320 de Regularización de Títulos Jurídicos de Inmuebles del Domino Privado del Estado.

Gobierno de la Provincia de Buenos Aires (1977). Decreto Ley N 8912. Ordenamiento Territorial y Uso del Suelo.

Gobierno del Municipio de Moreno (2016). Ordenanza Municipal № 5.686.

Gobierno del Municipio de Moreno (2008). Código de Zonificación.

HARDOY, J. Y SATTERWHITE, D. (1987). La ciudad legal y la ciudad ilegal. Buenos Aires: GEL.

IZAGUIRRE, I. Y ARISTIZÁBAL, Z. (1988). Las tomas de tierras en la zona sur del Gran Buenos Aires. Un ejercicio de formación de poder en el campo popular. Buenos Aires: Centro Editor de América Latina.

LASCOUMES, P. Y LE GALÉS, P. (2014). Sociología de la acción pública. México: El Colegio de México; Centro de Estudios Demográficos, Urbanos y Ambientales.

MERKLEN, D. (1997). Organización Comunitaria y Práctica Política. Las Ocupaciones de Tierras en el conurbano de Buenos Aires. Revista Nueva Sociedad, (149).

REESE, E. Y CATENAZZI, A. (2010). "Planificación e instrumentos de gestión del territorio". En Gestión municipal y ciudad. Dilemas y oportunidades. Programa de Mejora de la Gestión Municipal. Ministerio del Interior

SOLÁ-MORALES I RUBIÓ, M. (1997). Las Formas de Crecimiento Urbano. Ediciones UPC. Barcelona

TORRES, H. (1993). El Mapa Social de Buenos Aires (1940-1990). Ed. Dirección de investigaciones, FADU, UBA. Buenos Aires. 